This is a revised personal version of the text of the final journal article, which is made available for scholarly purposes only, in accordance with the journal's author permissions. The full citation is:

Heaven, S., Banks, C.J., Pak, L.N. and M.K. Rspaev (2007) Wastewater reuse in central Asia: implications for the design of pond systems. Water Science \& Technology Vol 55 No 1-2 pp 8593 (c) IWA Publishing 2007

doi 10.2166/wst.2007.061, http://www.iwaponline.com/wst/05501/wst055010085.htm

\title{
Wastewater reuse in central Asia: implications for the design of pond systems
}

\author{
S. Heaven*, C. J. Banks*, L.N. Pak** and M.K. Rspaev** \\ * School of Civil Engineering and the Environment, University of Southampton, Southampton, SO17 1BJ, UK (E- \\ mail: sh7@soton.ac.uk) \\ ** BG Chair of Environmental Technology, Almaty Institute of Power Engineering and telecommunications, 126 \\ Baytursynov Street, Almaty 480013, Kazakhstan
}

\begin{abstract}
The paper examines the potential of waste stabilisation ponds to provide water for reuse in extreme continental climates such as those of central Asia, where precipitation is low and summer evaporation rates are high. A simple model is used to predict water availability, BOD and faecal coliform removal for different configurations and operating regimes. The results show a significant proportion of flows could be saved for irrigation or aquifer and river replenishment; if standard designs can be modified to suit these climates, the system is likely to be both more robust and more flexible in terms of types of reuse. The paper concludes with 3 case studies of evaporation pond systems in Kazakhstan, assessing their potential for conversion to full biological treatment systems for water conservation and reuse.
\end{abstract}

Keywords continental climate, evaporation, waste stabilisation ponds, wastewater reuse

\section{INTRODUCTION}

The Central Asian region has a sharply continental climate characterised by cold winters, hot summers and very low precipitation, making water a precious resource. Despite this, evaporation ponds are widely used as a means of wastewater disposal, for both industrial and domestic effluents. In Kazakhstan alone more than 500 such pond systems are believed to be in operation. In comparison with evaporation ponds, waste stabilisation pond (WSP) systems offer major advantages: they can provide treated water for a variety of uses, including irrigation through summer and high-quality water for top-up of rivers or aquifers in autumn. Under certain conditions they may also retain water within a catchment, which would otherwise be lost during the winter period. Design guidelines for continental WSPs are less developed than for tropical or temperate areas, however, and in most cases appear to be based on cold climate systems, without taking into account the greater importance of reuse and the significance of high evaporation losses. This paper looks at some aspects of the design and operation of pond systems in Kazakhstan and Central Asia, and considers their implications for water conservation and reuse.

For ponds subject to seasonal ice cover, a widely-adopted design and operating regime is that of intermittent discharge, consisting of treatment plus storage for 6-12 months (US EPA, 1983; 
Prince et al., 1995). Pond working depths are specified, and the surface loading rate on the first pond is limited. In cold regions this produces a high-quality effluent that can be discharged in a short period, usually in autumn. This approach is robust but may be conservative in warmer continental climates, where the spring warm-up is rapid and treatment capacity in summer months is greater. To determine the impact of some potential design and operational changes on water availability, a simple model was constructed and operated under different scenarios.

\section{MATERIALS AND METHODS}

The model simulates a WSP system in central Kazakhstan, consisting of a facultative pond (FP) and one or more storage/maturation ponds (SMP). The wastewater flow rate was taken as 1000 $\mathrm{m}^{3}$ day $^{-1}$, with a biochemical oxygen demand (BOD) of $200 \mathrm{mg} \mathrm{l}^{-1}$ and a faecal coliform (FC) concentration of $4 \times 10^{8} 1^{-1}$.

Model construction. The model calculates mass balances for wastewater volumes, BOD and FC using a one-day time-step. Wastewater volumes are calculated taking into account inflow, outflow, evaporation and precipitation and assuming a lined system with no infiltration. The ponds are assumed to be simple rectangles in plan, with no allowance made for the variation of area with depth and side slope. BOD and FC concentrations are calculated assuming first-order decay kinetics. The decay constant $k$ is assumed to follow an Arrhenius equation of the form $k_{\mathrm{T}}=$ $k_{20} \theta^{(\mathrm{T}-20)}$, where $k_{\mathrm{T}}$ and $k_{20}$ are values of $k$ at temperatures of $\mathrm{T}{ }^{\circ} \mathrm{C}$ and $20{ }^{\circ} \mathrm{C}$ respectively. Parameter values used were $\theta_{\mathrm{BOD}}=1.08$ and $k_{20 \mathrm{BOD}}=0.25$ (Mara, 1976); and $\theta_{\mathrm{FC}}=1.19$ and $k_{20}$ $\mathrm{FC}=2.6$ (Marais, 1974).

The FP is modelled by specifying a BOD surface loading rate and a working depth, thus fixing the surface area, volume and mean hydraulic retention time for a given inflow and influent BOD concentration. Once the surface area is known, daily and total outflows are calculated based on inflow minus evaporation and precipitation. The mass of BOD or FC in the pond is calculated based on the initial value, inputs, decay and discharge, and the daily effluent concentrations are obtained by dividing the total mass of BOD or FC by the pond volume.

The design of the SMP is determined by choosing a maximum working depth and a discharge period. The SMP is assumed to be empty at the end of the discharge period. The procedure is to guess an appropriate surface area for the SMP, from which total and daily values of evaporation and precipitation are calculated. The outflow from the SMP is equal to inflow (corresponding to outflow from the FP minus any direct discharges), minus evaporation and plus precipitation; daily outflows are obtained from the total outflow divided by the discharge period. The maximum volume stored in the SMP is equal to the total outflow, plus evaporation during the discharge period, and minus precipitation in the same period. From the maximum volume and chosen area a depth is calculated. If this depth is greater than the preferred maximum working depth for the SMP, the area must be increased and the calculation repeated. Once a satisfactory result is obtained, daily values are used to calculate pond depth and effluent BOD and FC concentrations. Under some operating regimes a SMP may stand empty for some time, for example if inflow is diverted elsewhere and evaporation exceeds precipitation. In this case total outflow is adjusted by the theoretical contribution from evaporation and precipitation during the period while the pond is empty. 
Climate data. Mean monthly climate data were taken for Astana weather station located at 51.2 N, 71.4 ${ }^{\mathrm{O}} \mathrm{E}$ (Hong Kong Observatory, 2005) and are summarised in Table 1. Evaporation was calculated for a reference surface using CROPWAT software (Clarke et al., 1998), and increased by $10 \%$ to give values for an open water surface. Daily evaporation and air temperatures were obtained from mean monthly values by polynomial interpolation. Water temperature was assumed to equal air temperature down to $0{ }^{\circ} \mathrm{C}$, and to remain at zero for lower air temperatures. Daily precipitation values were obtained by dividing the mean monthly value by the number of days in the month.

Table 1 Climate data used in standard model (based on Astana weather station)

\begin{tabular}{|c|c|c|c|c|c|c|c|c|c|c|c|c|c|c|}
\hline Parameter & Jan & Feb & Mar & Apr & May & Jun & Jul & Aug & Sep & Oct & Nov & Dec & Year & \\
\hline Mean temperature ${ }^{\circ} \mathrm{C}$ & -15.8 & -15.9 & -8.1 & 4.9 & 13.1 & 19.0 & 21.3 & 17.7 & 12.0 & 2.8 & -5.9 & -12.6 & 2.7 & (mean) \\
\hline Precipitation $\mathrm{mm}$ & 17.4 & 13.7 & 14.3 & 22.0 & 33.4 & 34.8 & 49.5 & 39.7 & 24.0 & 29.6 & 21.7 & 17.3 & 317.4 & (sum) \\
\hline Evaporation* $\mathrm{mm}$ & 4.4 & 7.1 & 18.8 & 80.2 & 156.9 & 196.0 & 193.0 & 150.4 & 101.3 & 41.3 & 10.2 & 3.8 & 963.3 & (sum) \\
\hline Mean daily sunshine hours & 3.3 & 5.2 & 6.2 & 7.9 & 9.7 & 11.2 & 10.8 & 9.5 & 7.7 & 4.4 & 3.3 & 3.0 & 6.9 & (mean) \\
\hline
\end{tabular}

Model validation. BOD concentrations predicted by the model were tested using BOD and chemical oxygen demand data from experimental ponds in Almaty, Kazakhstan (Heaven et al., in review;). The model was run with both mean daily air temperatures obtained from monthly values as above, and with actual mean air temperatures.

Modelling scenarios. Options considered are summarised in Table 2 and included:

- A conventional design based on a 2-stage system of a $1 \mathrm{~m}$ deep FP and a $2 \mathrm{~m}$ deep SMP. The loading rate on the FP is limited to $40 \mathrm{~kg} \mathrm{BOD} \mathrm{ha}^{-1}$ day $^{-1}$ due to seasonal ice cover and the system operates with a single autumn discharge (1-30 September).

- Increasing the loading rate on the FP pond to $100 \mathrm{~kg} \mathrm{BOD} \mathrm{ha}^{-1} \mathrm{day}^{-1}$, thus reducing the surface area and hydraulic retention time

- Increasing the depth of the SMP from 2 to $4 \mathrm{~m}$, to reduce surface area.

- Increasing both FP loading rate and SMP depths.

- As above but replacing a single SMP with two ponds in parallel that store and discharge water in alternate years. Effluent treated to a high standard by the end of the summer is stored over winter without any further addition of incoming wastewater, and is available for irrigation from early spring, thus maximising its economic usefulness.

Table 2 Options considered

\begin{tabular}{|c|c|c|c|c|c|c|c|}
\hline \multicolumn{2}{|c|}{ Case } & \multicolumn{3}{|l|}{ Facultative } & \multicolumn{2}{|c|}{ Storage/maturation } & \multirow{2}{*}{\begin{tabular}{|l|} 
Total \\
Area
\end{tabular}} \\
\hline & & BOD load & Depth & Area & Depth & Area & \\
\hline \multicolumn{2}{|c|}{ Single storage/maturation pond } & $\mathrm{kg} \mathrm{ha}^{-1}$ day $^{-1}$ & $\mathrm{~m}$ & ha & $\mathrm{m}$ & ha & ha \\
\hline $1 \mathrm{a}$ & Standard design & 40 & 1.0 & 5.00 & 2.0 & 11.80 & 16.80 \\
\hline $1 \mathrm{~b}$ & Standard with discharge July-August & 40 & 1.0 & 5.00 & 2.0 & 11.80 & 16.80 \\
\hline 1c & Increased loading rate FP & 100 & 1.0 & 2.00 & 2.0 & 12.30 & 14.30 \\
\hline 1d & Increased depth SMP & 40 & 1.0 & 5.00 & 4.0 & 6.44 & 11.44 \\
\hline 1e & Increased loading rate FP and depth SMP & 100 & 1.0 & 2.00 & 4.0 & 6.71 & 8.71 \\
\hline \multicolumn{8}{|c|}{ Parallel storage/maturation ponds } \\
\hline $2 a$ & Parallel SMPs & 40 & 1.0 & 5.00 & 2.0 & 12.60 & 30.20 \\
\hline $2 b$ & Increased loading rate FP & 100 & 1.0 & 2.00 & 2.0 & 13.35 & 28.70 \\
\hline 2c & Increased depth SMPs & 40 & 1.0 & 5.00 & 4.0 & 7.17 & 19.34 \\
\hline $2 d$ & Increased loading rate FP and depth SMPs & 100 & 1.0 & 2.00 & 4.0 & 7.59 & 17.18 \\
\hline
\end{tabular}




\section{RESULTS AND DISCUSSION}

\section{Water quantity}

Table 3 shows the amount of water potentially available for reuse, based on the results of modelling. The greatest gain comes simply from replacing evaporation ponds with WSPs: in comparison with a theoretical $100 \%$ loss, the standard design with a single autumn discharge (1a) allows use of $70 \%$ of the original inflow. Experience in Canada and the northern USA shows effluent quality in this period can be extremely high (Prince et al., 1995), making it potentially suitable for aquifer or river replenishment. The water is of greater economic value if it is available in the growing season, which in central Asia can run from April-October depending on crop, latitude and altitude: a more usual period is May-August, but pre-irrigation of the soil in April or May is also common to make up the previous year's moisture deficit. If the water is of a suitable quality for reuse between July-August, it is available for at least the later part of the irrigation period (1b).

Table 3 Water available for reuse under different scenarios

\begin{tabular}{|c|c|c|c|c|c|c|c|}
\hline \multicolumn{2}{|c|}{ Case } & \multicolumn{3}{|c|}{ Net loss as \% of original inflow } & \multicolumn{3}{|c|}{ Water available for re-use } \\
\hline & & $F P$ & SMP & Total & \% of inflow & Main discharge & Possible uses \\
\hline $1 \mathrm{a}$ & Standard design & $9 \%$ & $21 \%$ & $30 \%$ & $70 \%$ & September & River/aquifer replenishment \\
\hline $1 b$ & standard but disch July-Aug & $9 \%$ & $21 \%$ & $30 \%$ & $70 \%$ & July-August & Late irrigation, river/aquifer \\
\hline $1 c$ & Increased loading rate FP & $4 \%$ & $22 \%$ & $26 \%$ & $74 \%$ & July-August & Late irrigation, river/aquifer \\
\hline $1 d$ & Increased depth SMP & $9 \%$ & $12 \%$ & $21 \%$ & $79 \%$ & July-August & Late irrigation, river/aquifer \\
\hline $1 \mathrm{e}$ & Increased loading FP and depth SMP & $4 \%$ & $12 \%$ & $16 \%$ & $84 \%$ & July-August & Late irrigation, river/aquifer \\
\hline $2 a$ & Parallel SMPs & $9 \%$ & $52 \%$ & $61 \%$ & $39 \%$ & April-August & All \\
\hline $2 b$ & Increased loading rate FP & $4 \%$ & $49 \%$ & $53 \%$ & $47 \%$ & April-August & All \\
\hline $2 \mathrm{c}$ & Increased depth SMPs & $9 \%$ & $34 \%$ & $43 \%$ & $57 \%$ & April-August & All \\
\hline $2 d$ & Increased loading FP and depth SMPs & $4 \%$ & $30 \%$ & $33 \%$ & $67 \%$ & April-August & All \\
\hline
\end{tabular}

The volume of water available can be increased by increasing the loading rate on the FP (1c): experimental work on pilot-scale ponds in Kazakhstan suggests this is possible without adversely affecting performance (Heaven et al., in review). A more significant impact is produced by increasing the depth of the SMP. This may be justifiable as its primary function is storage, and light penetration is less important than in a FP, although playing a role in disinfection. An increase in depth implies higher construction costs, although in practice SMPs are sometimes located in natural depressions. If both of these design modifications can be adopted (1e), the amount of available water rises to $84 \%$. In the standard design with two SMPs, availability falls to $39 \%$; but this covers the whole growing season, and all types of reuse. Economic assessment is needed to determine whether the higher capital costs for construction of two ponds are outweighed by the value of the water. If it is possible both to increase the depth of the SMPs and to load the FP more heavily (2b-d), the available volume rises to as much as $67 \%$. The scale of the potential savings for reuse indicates the need for larger studies to confirm whether these or other modifications live up to their promise in practice.

\section{Water quality}

$B O D$. The model fitted the Almaty data moderately well: at high loadings in particular, effluent BOD fell too rapidly in early spring; while summer BOD values tended to be overestimated in FPs and underestimated in SMPs. These discrepancies may be explained by a wide range of factors not included in the model: e.g. effects of nutrient release from pond sediments, existence of a lag phase before the spring algal bloom, higher water temperatures in late summer, and changes in pond population characteristics during the year. More complex models exist, but problems often arise in obtaining parameter values, especially for lower temperature ranges. 
Better fitting can be achieved by choosing different parameter values for each dataset and season, but this is to overstretch both the model and the available data. While the output is thus indicative rather than exact, the model was considered adequate for its purpose. Figure 1 shows some results from the Almaty ponds. The data also revealed significant year-to-year variability, which may be directly due to temperature variations in a given year (e.g. an early spring or hard winter), or to more complex ecosystem interactions.
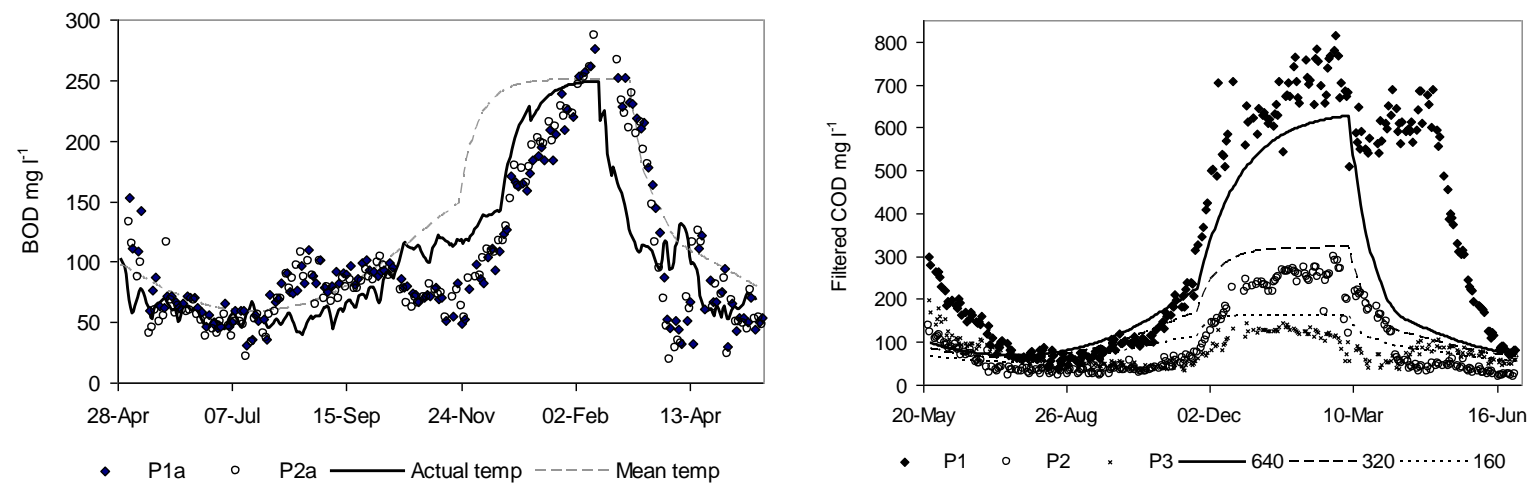

Figure 1 Real and modelled Almaty pond results for a) mean and actual temperature at $250 \mathrm{mg} \mathrm{l}^{-}$ ${ }^{1}$ influent BOD and b) mean temperature at 160, 320, $640 \mathrm{mg} \mathrm{l}^{-1}$ influent COD

All the single SMP options modelled (1a-e) achieved low BODs $\left(<5 \mathrm{mg} \mathrm{l}^{-1}\right)$ from July onwards. While actual values should be viewed with caution, this matches the observation by Prince $e t$ al. (1995) that loading rate has little effect on final effluent quality in intermittent discharge ponds. The main gains in water availability would result from increasing SMP depths and FP loading rates: the model indicates this may be possible, but again there is insufficient real data for design guidelines. The cases with two SMPs (2a-d) all had very low BODs throughout the 'rest' period, making water available for all reuse options. Actual results from SMPs may be higher and more variable, but the two-pond system is clearly robust, and may have additional benefits in balancing out the nutrient load from sediments. Figures 2 and 3 present key parameters for cases $1 \mathrm{a}$ and $2 \mathrm{a}$, clearly showing the extended period of low BOD in case $2 \mathrm{a}$.

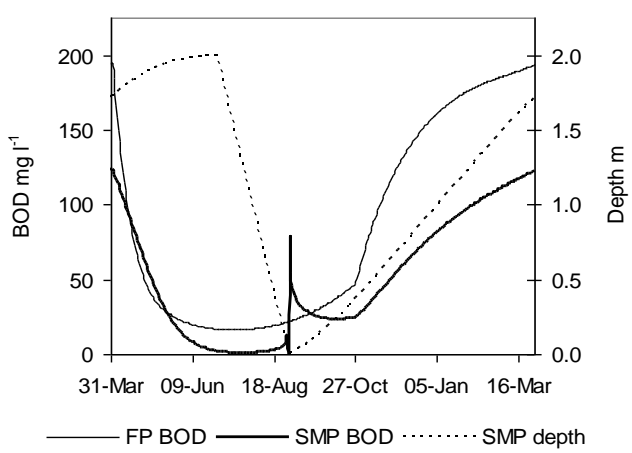

Figure 2 BOD and depth for Case 1a

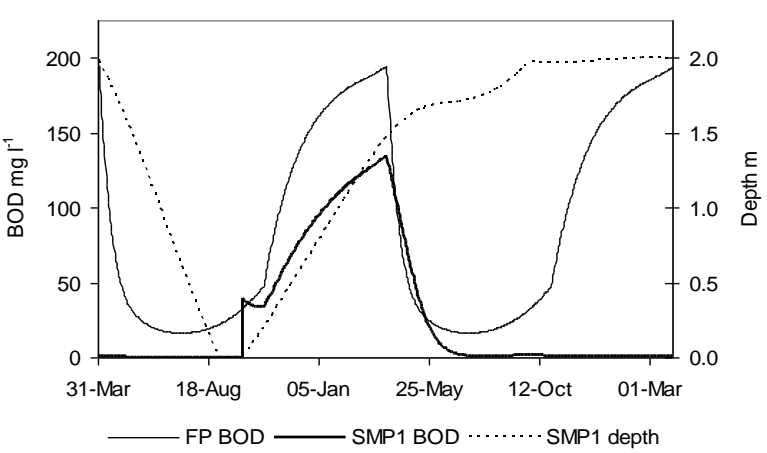

Figure 3 BOD and depth for Case $2 \mathrm{a}$

$F C$. For reuse in irrigation, microbiological quality parameters are critical. WHO guidelines suggest values of $10^{3} \mathrm{FC}$ per $100 \mathrm{ml}$ for unrestricted irrigation and $10^{5} \mathrm{FC}$ per $100 \mathrm{ml}$ for restricted irrigation (WHO, in review). Modelling of FC gave results similar in form to those for 
BOD, but with more rapid winter die-off in the SMP. Reductions in the FP were typically of one order. The single SMP pond achieved levels below $10^{5} \mathrm{FC}$ per $100 \mathrm{ml}$ from end April to end August (end September for 1a); and below $10^{4}$ from mid May to mid August for lower FP loadings (1a, 1b and 1d), and early June to late July at higher loadings (1c and 1e). In systems with two SMPs (2a-d), FC concentrations were below $10^{3}$ per $100 \mathrm{ml}$ from November and negligible from May onwards in the 'rest' year.

Results for FC should be viewed with even more caution than those for BOD. Unfortunately no local data were available for model testing, as the Almaty pilot ponds were fed with a synthetic wastewater. Values of $k_{F C}$ and $\theta_{\mathrm{FC}}$ were taken from Marais (1974), and are said to be valid from 2-21 ${ }^{\circ} \mathrm{C}$; but they assume aerobic conditions with complete mixing, and were derived from ponds with a 12-day retention period. There is evidence from both laboratory studies and field sampling, however, of extended survival of pathogen indicator organisms in storage ponds at low temperatures (Environment Canada, 1985; Torrella et al., 2003). Once again, more studies are needed to provide an adequate basis for design. Marais (1974) noted that single large ponds for winter storage are a practical solution in cold climates due to the limited pathogen reduction; while above $21{ }^{\circ} \mathrm{C}$ there is an apparent reduction in $k_{F C}$, leading to lower die-off rates. In continental climate areas, which can move relatively rapidly from one temperature range to the other, special guidelines may be needed to ensure both safe and efficient reuse.

\section{CASE STUDIES}

Case study 1. The industrial site in this study is located in north-east Kazakhstan, where mean monthly temperatures range from $-13{ }^{\circ} \mathrm{C}$ in January to $+23{ }^{\circ} \mathrm{C}$ in July, with an annual mean of 5 ${ }^{\circ} \mathrm{C}$. Annual precipitation is $302 \mathrm{~mm}$ and evaporation $957 \mathrm{~mm}$. Domestic-type wastewater flows of $55 \mathrm{~m}^{3}$ day $^{-1}$ are generated by the site's administrative block. The wastewater receives primary sedimentation and biological treatment in a package plant, followed by rapid sand filtration and final discharge into a storage/ evaporation pond with a capacity of $20000 \mathrm{~m}^{3}$. In the Soviet period it was planned to use the treated wastewater for irrigation, but no infrastructure was set up; the land nearby is not very suitable for agriculture and it is now unlikely this will happen. Due to problems with equipment and operator training the package plant does not work well. Performance is assessed on the quality of the discharge into the storage/evaporation pond, which fails to meet a number of the parameters set by the local Environmental Protection Department (EPD). The site operators are coming under pressure to replace the treatment plant, and to line the pond to prevent seepage and potential groundwater contamination. The capacity of the present pond taking into account precipitation, evaporation and infiltration is about 5 years; without infiltration this would be reduced to 18 months. The influent wastewater BOD is extremely low at $60 \mathrm{mg} \mathrm{l}^{-1}$, however, and one alternative would be to modify the pond into a full biological treatment system. If loading on the first FP is limited to $40 \mathrm{~kg} \mathrm{BOD} \mathrm{ha}^{-1} \mathrm{day}^{-1}$, an area of $825 \mathrm{~m}^{2}$ is required. The existing pond is $2 \mathrm{~m}$ deep, giving an HRT of 30 days; if desired this could be reduced to $1 \mathrm{~m}$, as heavy earth-moving equipment and spoil materials are available on site. Using the model and climate details above, a SMP with once-per-year discharge would require an area of approximately $6600 \mathrm{~m}^{2}$. An FP and SMP could be constructed by subdividing the existing pond: in practice it would be preferable to add more FPs. A small river runs through the site, with high seasonal variations in its flow. The treated water could potentially be discharged to the river in late summer and autumn, when effluent quality is expected to be high, 
to support increased biodiversity and provide some aquifer recharge.

Case study 2. The study considers a similar plant in central Kazakhstan, where mean monthly temperatures range from $-9{ }^{\circ} \mathrm{C}$ in January to $+28{ }^{\circ} \mathrm{C}$ in July. The region is arid, with average annual precipitation less than $150 \mathrm{~mm}$ and evaporation around $1000 \mathrm{~mm}$. The potable water supply comes from boreholes located several kilometres from the plant. Wastewater flows generated by on-site accommodation and offices for about 1000 staff are officially reported as $245,000 \mathrm{~m}^{3}$ year $^{-1}$, but flow measurement suggests a real value of around 45,000 $\mathrm{m}^{3} \mathrm{year}^{-1}$. Wastewater is discharged into unlined holding ponds each $40 \mathrm{~m}$ x $60 \mathrm{~m}$ and $1.5 \mathrm{~m}$ deep: when one pond becomes full another is excavated. The company wishes to upgrade its wastewater management to provide an effective treatment system. Treated wastewater could be used to grow vegetables for on-site consumption, as the site is remote and deliveries are logistically complex. Microbiological quality is therefore critical, and it would be relatively simple to modify the existing layout to a series of ponds with retention times of approximately 30 days. The effect of seasonal variations in HRT due to evaporation is insignificant compared with variations in $k_{\mathrm{FC}}$. The system could generate sufficient water to irrigate approx 2 ha under local conditions. Construction costs for a lined pond system are comparable with those for a package plant, while operation and maintenance should be simpler.

Case study 3. This study concerns a large process plant in western Kazakhstan, where the climate is modified by the nearby Caspian Sea, and temperatures are above $10{ }^{\circ} \mathrm{C}$ for $170-180$ days per year. Workers living on the site produce domestic wastewater flows of $1200 \mathrm{~m}^{3}$ day $^{-1}$, which are discharged without pre-treatment to a system of evaporation ponds. The system consists of two components: a single pond of 25 ha and $1 \mathrm{~m}$ depth, which began operation in 1985; and a 5 ha pond divided into four sections of $1.5 \mathrm{~m}$ depth, completed in 1999. Water depths in summer are typically no more than a few tens of centimetres. The local EPD regards the ponds as a means of disposal rather than a treatment system: stringent discharge standards are imposed and, since there is no outlet, these are assessed against samples taken from the inlet to the pond system. As a result, a number of parameters routinely exceed permitted concentrations. The system could be redesigned as above, to produce a flow of treated wastewater for on-site irrigation in the summer months; the creation of a defined discharge point might also allow re-negotiation of the discharge consent on a more rational basis. At present water for domestic use is piped $600 \mathrm{~km}$ from the Volga river, treated to potable standard and stored: some is used for site irrigation, and reuse would therefore represent a significant saving. In view of the high cost of water, however, and the existence of other year-round uses for it on the site, in this case it may be more effective to provide a conventional mechanical-biological treatment plant. In addition the plant produces 500 $\mathrm{m}^{3}$ day $^{-1}$ of heavily contaminated water, which is piped to separate treatment plant; and $1700 \mathrm{~m}^{3}$ day $^{-1}$ of process water and storm drainage, sent to evaporation ponds. The evaporation ponds are undersized and cause periodic flooding: these too could be re-designed, but present a more difficult case for reuse because of potential chemical contamination.

\section{CONCLUSIONS}

Simply replacing evaporation ponds with intermittent discharge WSP systems may make a large proportion (70\% or more) of wastewater flows potentially available for reuse. Standard designs and operating regimes for these systems are known to work well in cold climates, although the 
range of reuse applications may be limited by discharge timing. The guidelines may however be conservative for continental climates, where high levels of performance in the warm period may make it possible to reduce surface areas, leading to lower evaporation losses. Results from a simple model give at least qualitative support to these ideas. More complex models exist, but their use is limited by a lack of parameter and coefficient values for lower temperature ranges, and of fundamental understanding of the processes occurring in ponds subject to strong seasonal variation. Currently available information is not reliable enough as a basis for design, but strongly suggests that there may be advantages in developing design and operating protocols specifically for continental climate systems. Year-to-year variability in continental climates may mean that robust systems are needed, such as alternating storage ponds; in this case minimising surface area is vital to reduce losses and maximise the availability of water for reuse. Case studies support the idea that such changes could make an impact in practice.

\section{ACKNOWLEDGEMENTS}

The authors gratefully acknowledge the support of EU INCO-Copernicus CT98-0144, INTAS KZ 96-1864, and the BG Foundation, which enabled them to carry out this work.

\section{REFERENCES}

Clarke, D., Smith, M., and El-Askari, K. (1998). New software for crop water requirements and irrigation scheduling. J Int. Commission Irrig. Drainage. 47(2), 45-58.

Environment Canada (1985). Sewage Lagoons in cold climates. Report EPS 4/NR/1. Technical Services Branch. Environment Canada, Ottawa.

Heaven, S., Banks, C.J., Pak, L.N. and Rspaev, M.K. (in review). Seasonal responses of continental climate waste stabilisation ponds: potential implications for design and operation. Wat. Qual. Res. J. Canada.

Hong Kong Observatory (2005). Climatological Information for Astana, Kazakhstan accessed 28/06/2005 www.hko.gov.hk/wxinfo/climat/world/eng/asia/westasia/astana_e.htm.

Marais, G.V.R. 1974. Faecal Bacterial Kinetics in Stabilization Ponds. Journal of the Environmental Engineering Division ASCE EE1(100), 119-139.

Mara, D.D. (1976). Sewage treatment in hot climates. John Wiley \& Sons, Chichester, UK.

Prince, D.S., Smith D.W., and Stanley, S.J. (1995). Performance of lagoons experiencing seasonal ice cover. Water Environment Research 67(3), 318-326.

WHO (in press) WHO Guidelines for the safe use of wastewater in agriculture. Protection of the Human Environment Department, World Health Organization, Geneva.

Torrella, F., Lopez, J.P., and Banks, C.J. (2003). Survival of indicators of bacterial and viral contamination in wastewater subjected to low temperatures and freezing: application to cold climate waste stabilisation ponds. Wat. Sci. Technol. 48: 105-112.

US EPA (1983). Design Manual: Municipal Wastewater Stabilization Ponds. Report 625/1-83015, US Environmental Protection Agency, Cincinnati, Ohio. 